\title{
ZBIGNIEW LEWICKI
}

Uniwersytet Kardynała Stefana Wyszyńskiego

\section{USTANAWIANIE AMERYKAŃSKIEJ WŁADZY KOLONIALNEJ NA FILIPINACH}

Przełom XIX i XX w. był okresem gwałtownego rozwoju kolonializmu. W latach 1878-1914 łączny obszar kolonii na świecie powiększył się o ponad $22 \mathrm{mln} \mathrm{km}^{2}$, a ich liczba znacznie przekroczyła $100^{1}$. Po raz pierwszy też i jedyny w swojej historii kolonię pozyskały Stany Zjednoczone. Stało się tak w wyniku zwycięskiej wojny z Hiszpanią, ale decyzję o akceptacji nowej sytuacji poprzedziła intensywna debata w samej Ameryce ${ }^{2}$.

Nikt praktycznie nie kwestionował koncepcji geostrategicznej adm. Alfreda Thayera Mahana, zakładającej stworzenie sieci baz, szczególnie na Oceanie Spokojnym, jako koniecznego zaplecza logistycznego dla coraz potężniejszej floty amerykańskiej. Czym innym było jednak powszechne zrozumienie dla potrzeby zachowania kontroli na Manilą czy portem Cavite na wyspie Luzon, a czym innym objęcie w posiadanie ponad 7 tysięcy wysp, zamieszkałych przez ok. 8 mln ludzi i wchodzących w skład archipelagu oddalonego o kilkanaście tysięcy kilometrów od USA. Na dobrą sprawę jedynym argumentem przemawiającym za takim rozwiązaniem była oczywista niedogodność sytuacji, w której

\footnotetext{
1 Por. T. Boswell, Colonial Empires and the Capitalist Word-Economy, «American Sociological Review» 54/1989, s. 186.

2 O ile sama wojna $z$ Hiszpanią jest omawiana w praktycznie wszystkich polskich historiach Stanów Zjednoczonych, o tyle nikt z polskich badaczy nie zajmował się dotąd bliżej kwestią ustanawiania administracji amerykańskiej na Filipinach.
} 
Stany Zjednoczone kontrolowałyby kilka miast i portów filipińskich, podczas gdy tereny wokół nich znajdowałyby się w rękach nieprzyjaznej Hiszpanii. Ostatecznie 28 października 1898 r. prezydent William McKinley po, jak sam twierdził, zasięgnięciu rady u Boga, przekazał amerykańskim negocjatorom swoją decyzję:

„Przejęcia samej wyspy Luzon przy pozostawieniu reszty wysp pod władzą Hiszpanii albo jako przedmiotu dalszych sporów nie da się uzasadnić względami politycznymi, handlowymi czy humanitarnymi. Dlatego można przejąć wszystko albo nic. Ta druga możliwość jest nie do zaakceptowania, co sprawia, że pierwsza jest nie do uniknięcia"3.

21 grudnia 1898 r. zawarto traktat paryski kończący wojnę między Stanami Zjednoczonymi a Hiszpanią. Jednym z jego postanowień, zawartym w art. III, był wymuszony przez Waszyngton zakup Filipin: „Hiszpania ceduje na Stany Zjednoczone archipelag zwany Wyspami Filipińskimi... Stany Zjednoczone zapłacą Hiszpanii sumę dwudziestu milionów dolarów"4. Sprzeciw, jaki budziło przekazanie tak znacznej sumy ${ }^{5}$ za terytorium znajdujące się już we władaniu Stanów Zjednoczonych, odpierano argumentem o tradycyjnej amerykańskiej „hojności w triumfie”. Pod kontrolę amerykańską przeszły też na mocy tego samego traktatu Porto Rico i Guam, ale ich ówczesna sytuacja oraz dalsze losy były odmienne i ich omówienie wymagałoby odrębnego opracowania.

Początkowo Filipinami zarządzali samodzielnie amerykańscy gubernatorzy wojskowi. Pierwszym z nich, mianowanym już 25 lipca 1898 r., był gen. Wesley Merritt, całkowicie pozbawiony zdolności dyplomatycznych. W swoim pierwszym rozkazie zabronił jakichkolwiek kontaktów z filipińskim przywódcą Emilio Aguinaldo, który uprzednio wsparł Amerykanów w walce z Hiszpanami. Już po miesiącu Merritt został jednak odkomenderowany do uczestniczenia w negocjacjach pokojowych w Paryżu. Jego stanowisko objął gen. Elwell Otis, równie, jak

\footnotetext{
3 Za E.T.L. Love, Race Over Empire, University of North Carolina Press, Chapel Hill 2004, s. 178.

4 http://avalon.law.yale.edu/19th_century/sp1898.asp, (dostęp 10 kwietnia 2014 r.).

5 Suma ta odpowiada w sile nabywczej kwocie 579 mln dolarów z 2013 r. Por. http://www.measuringworth.com/uscompare/ (dostęp 10 kwietnia 2014 r.).
} 
poprzednik, napuszony i pretensjonalny, posiadający predyspozycje nie tyle do uporania się ze skomplikowaną sytuacją polityczno-militarną, ile do „dowodzenia fortem w Arizonie z jedną kompanią żołnierzy”, jak ujął to ówczesny papieski wysłannik na Filipiny ${ }^{6}$. Nieudolność Otisa sprawiła, że konflikt z Aguinaldo, możliwy do załagodzenia zanim się $\mathrm{w}$ pełni rozwinął, przerodził się $\mathrm{w}$ długotrwałą kampanię $\mathrm{z}$ wieloma ofiarami po obu stronach.

4 lutego 1899 r. Emilio Aguinaldo ogłosił się prezydentem i tzw. rewolucja filipińska rozpoczęła się. Łącznie wzięło w niej udział ok. 80 tys. Filipińczyków, podczas gdy Amerykanie dysponowali siłami liczącymi ponad 120 tys. żołnierzy, ale bezustanne nękanie ze strony powstańców dawało efekty. W maju 1900 r. gubernatorem wojskowym Filipin został gen. Arthur MacArthur, który wprowadził amnestię dla uczestników powstania wraz z premią za każdą oddaną sztukę broni palnej. Spod działania amnestii wyłączono jednak osoby, które prowadziły działania niezgodne z ,zasadami cywilizowanej walki”, co w efekcie uzależniało jej zastosowanie od subiektywnych decyzji poszczególnych dowódców wojskowych. Między innymi z tego powodu amnestia przyniosła ograniczone efekty i pojawiały się nawet opinie, że korzystali z niej głównie posiadacze starej i niesprawnej broni, pragnący jedynie uzyskać premię za jej złożenie.

Ponoszone przez armię amerykańską ofiary sprawiały zarazem, że nasilały się żądania surowych represji wobec powstańców, z zastosowaniem tortur włącznie. Możliwość taką implikował sam MacArthur, odmawiając ludziom Aguinaldo miana żołnierzy:

„Osoby, które biorą udział w walkach, nie będąc członkami regularnych zorganizowanych sił i nie uczestnicząc stale w ich działaniach, lecz powracając co pewien czas do swych domów i zawodów, zrzekają się miana żołnierzy, a schwytane nie mogą liczyć na przywileje przysługujące jeńcom wojennym"?.

6 Za S.C. Miller, Benevolent Assimilation, Yale University Press, New Haven 1982, s. 46.

7 Ibidem, s. 163. 
Pod groźbą odesłania do kraju dowództwo zakazało też dziennikarzom amerykańskim przekazywania informacji o traktowaniu powstańców.

Sytuacja zmieniła się, gdy w marcu 1901 r. Amerykanie pochwycili Aguinaldo. Rozpatrywano możliwość i celowość postawienia go przed sądem, ale trudno było wskazać, o co miałby zostać oskarżony. On sam zresztą ubiegł takie zamierzenia, gdyż z własnej woli złożył przysięgę na wierność Stanom Zjednoczonym, a następnie wezwał swoich zwolenników do pójścia w jego ślady. Wielu z nich usłuchało zalecenia, a względna masowość takiego postępowania zdjęła z Aguinaldo odium zdrady czy tchórzostwa. W lecie 1901 r. walka zbrojna na Filipinach wyraźnie osłabła, a armia otrzymała rozkaz wprowadzania w miastach filipińskich zasad czystości i higieny, co oznaczało m.in. zmuszanie mieszkańców do mycia ulic i poddawania się odwszawianiu. Nadal jednak na wyspach pozostawały dwa aktywne ośrodki oporu: w południowej części wyspy Luzon i na archipelagu Sulu, zamieszkałym przez tzw. Moro, czyli filipińską ludność muzułmańską o zróżnicowanym pochodzeniu etnicznym. Jednoczyła ich głównie niechęć do innych mieszkańców wysp, w tym szczególnie do chrześcijan, będących na Filipinach w zdecydowanej większości.

Do najbardziej dramatycznych wydarzeń tej fazy walk doszło 28 września 1901 r. w miejscowości Balangiga na wyspie Samar, gdzie mieszkańcy zamordowali 48 żołnierzy amerykańskich, co spowodowało szerokie i brutalne działania retaliacyjne. Ich dokładne rozmiary nie są znane i stanowią do dziś przedmiot sporu historyków amerykańskich i filipińskich. Nikt jednak nie kwestionuje, że doszło do aktów zbrodni, za co dwaj oficerowie amerykańscy zostali skazani przez sąd wojskowy; trzeci z nich został uniewinniony, ale spotkało się to z krytyką korpusu oficerskiego. Przebieg wydarzeń stał się też przedmiotem dochodzenia kongresowego, które ustaliło, że armia amerykańska istotnie stosowała tortury. Nawet to nie zmieniło jednak opinii takich obserwatorów wydarzeń, jak chociażby korespondent agencyjny Charles Ballantine, który pisał w wydanej w 1902 r. książce: 
„Nasz mały «brązowy brat»... jest bez wątpienia nierzetelny, niegodny zaufania, ignorancki, złośliwy, niemoralny i leniwy... jest zdradziecki, a jako rasa jest bardziej nieuczciwy niż jakakolwiek inna rasa na ziemi"».

Walki z partyzantami filipińskimi trwały do 4 lipca 1902 r., kiedy to prezydent Theodore Roosevelt ogłosił ich zakończenie (choć pojedyncze grupy partyzantów toczyły je do 1905 r.).

Jeszcze w ich trakcie rozpoczęła się w Stanach Zjednoczonych poważna debata na temat przyszłości Filipin, zogniskowana wokół pytania, czy możliwe jest pogodzenie tradycyjnej koncepcji „amerykańskiej niewinności” z rzeczywistością mocarstwa kolonialnego. Próbowano się z tym uporać, redefiniując popularną pół wieku wcześniej koncepcję „widomego przeznaczenia” (Manifest Destiny), czyli podboju kontynentu w imię Boga i w celu szerzenia na nim cywilizacji. Jak stwierdził wpływowy senator Orville Platt: „Tak jak my kiedyś patrzyliśmy na bezkresny Zachód, tak nasze dzieci muszą spoglądać na oceany"9. W mniej wyrafinowanej wersji refleksje takie ustępowały miejsca jingoizmowi, czyli nacjonalistycznej wizji polityki zagranicznej zakładającej niepodlegającą dyskusji wyższość własnego kraju nad wszystkimi innymi.

Ideologia państwowa Stanów Zjednoczonych oparta była (i po części pozostaje) na koncepcji „amerykańskiej wyjątkowości”, czyli przekonania o specjalnej misji tego państwa i narodu jako wybranego przez Boga przykładu dla reszty świata. W pojęciu tym doskonale mieściła się wiara $\mathrm{w}$ „widome przeznaczenie”, ale trudno było przy jego pomocy uzasadnić prawo do wchodzenia w posiadanie kolonii. Czym innym była też chrześcijańska powinność nawracania sąsiadujących z Amerykanami Indian, a czym innym sprawowanie suwerennej władzy nad zamieszkującą dalekie wyspy ludnością, w 90\% chrześcijańską i jedynie w kilku procentach „pogańską”. Dlatego od samego początku swej obecności na Filipinach Amerykanie akcentowali, że postrzegają ją w kategoriach „łagodnej misji cywilizacyjnej” a nie kolonialnego imperializmu, zaś celem ostatecznym pozostaje niepodległość Filipin, gdy tylko będą na nią gotowe.

8 Ch. Ballentine, As It is in the Philippines, Bibliofile, Sussex 2009, s. 220-221.

9 Za S.C. Miller, op. cit., s. 5. 
Niemniej, wielu prominentnych polityków amerykańskich, pomnych historii swojego państwa, zdecydowanie sprzeciwiało się jego wejściu w rolę mocarstwa kolonialnego ${ }^{10}$. Szereg z nich dołączyło do utworzonej w 1898 r. Nowoangielskiej Ligi Antyimperialnej (New England Anti-Imperialist League), która szybko pozbyła się początkowego członu nazwy, by podkreślić swój ogólnonarodowy zasięg. Liga zrzeszała wiele osób o bardzo poważanych nazwiskach, cechował ją idealizm celów i środków, a przez kilka lat jej działalność była dostrzegana i doceniana. Na jej wiecach zaczęły się jednak pojawiać i wygłaszać sądy osoby o radykalnie lewicowych poglądach politycznych, co obciążało Ligę. Zasięg jej oddziaływania znacznie się zmniejszył i w 1904 r. powróciła do swojej pierwotnej nazwy.

Z kolei przeciwne opinie prezentowała utworzona w końcu $1900 \mathrm{r}$. organizacja zwana Philippine Information Society, publikująca raporty wychwalające postępowanie wojskowych władz amerykańskich na wyspie i dość powszechnie uważana za instytucję sterowaną przez administrację rządową.

Bez względu na stosowaną terminologię, nie sposób zaprzeczyć, że nabycie Filipin uczyniło ze Stanów Zjednoczonych imperium kolonialne. Ekspansja transoceaniczna bez zamiaru uczynienia z pozyskanych ziem części terytorium Stanów Zjednoczonych stanowiła oczywiste pogwałcenie pojęcia misji amerykańskiej. Michael W. Doyle przeprowadza w swej szeroko zakrojonej analizie imperiów rozróżnienie między imperiami sprawującymi władzę „nieformalnie” i „formalnie”"1. Choć Doyle nie zajmuje się bezpośrednio Filipinami, trudno nie dostrzec jakościowej różnicy między „nieformalną” kontrolą sprawowaną przez Stany Zjednoczone nad niepodległymi państwami Ameryki Łacińskiej a „formalnym", kolonialnym posiadaniem Filipin. Jak zauważył w 1905 r. William Willoughby, nabywszy ten kraj, Stany Zjednoczone „zdecydowanie weszły do grupy państw mających zagraniczne posiadłości kolonialne

10 Kwestię tę omawia szczegółowo R.E. WELCH, JR. w Response to Imperialism, University of North Carolina Press, Chapel Hill, 1979.

11 M.W. Doy Le, Empires, Cornell University Press, Cornell 1986. 
i zarządzających nimi"12. W konsekwencji Waszyngton musiał stworzyć nowy dla siebie mechanizm sprawowania władzy nad obszarem skolonizowanym. Nie mógł się przy tym posłużyć historią własnego państwa, gdyż XVII-wieczne kolonie angielskie w Ameryce miały charakter osadniczy, podczas gdy w przypadku Filipin w grę wchodziła jedynie kolonizacja administracyjna.

Do chwili zakończenia działań wojennych o wszelkich kwestiach dotyczących Filipin decydował prezydent Stanów Zjednoczonych jako głównodowodzący wojsk amerykańskich. Natomiast po zakończeniu walk uprawnienia takie miały przejść na Kongres, który jednak nie był przygotowany merytorycznie do tego zadania. Dlatego McKinley starał się przesądzić o dalszym biegu wydarzeń przed przekazaniem swych uprawnień legislaturze. Z jednej strony wydał Departamentowi Wojny polecenie podjęcia przygotowań do ustanowienia na wyspach władzy cywilnej, z drugiej zaś, jeszcze w 1899 r. powołał tzw. pierwszą komisję filipińską, znaną także jako komisja Schurmana, od nazwiska jej przewodniczącego, rektora Cornell University, Jacoba Goulda Schurmana. W jej skład wchodziło trzech cywilów i dwóch wojskowych, w tym gen. Otis.

W styczniu 1900 r. komisja przedstawiła prezydentowi szczegółowy raport, stwierdzając w konkluzji, że USA nie mogą wycofać się z Filipin. Powinny też dążyć do jak najszybszego tworzenia struktur samorządowych na wyspach, co gen. Otis uznał za sugestię przedwczesną i odmówił podpisania sprawozdania. Aby uniknąć otwartego konfliktu, prezydent posłużył się kolejną rekomendacją grupy, jaką była sugestia utworzenia komisji stałej z zadaniem opracowania kompleksowego planu działania dla Filipin. Na czele tego ciała, zwanego Komisją Filipińską, Philippine Commission, stanął młody, ale już wybitny prawnik William Howard Taft, który zrezygnował w tym celu ze stanowiska prezesa federalnego sądu apelacyjnego. Taft był przewodniczącym Komisji do 1 lipca 1901 r., kiedy to został cywilnym gubernatorem wysp. W 1904 r. objął stanowisko sekretarza wojny, a od 1909 r. kontrolował rozwój wydarzeń jako

12 W.F. Willoughby, Territories and Dependencies of the United States, Cornell University Library, Cornell 2009, s. 7. 
prezydent Stanów Zjednoczonych i lata 1900-1913 znane są w historii kolonialnych Filipin jako era Tafta.

Prace Komisji nadzorował w imieniu prezydenta sekretarz wojny Elihu Root, co miało zapewnić współdziałanie cywilnych i wojskowych instytucji administracji amerykańskiej na Filipinach. Od 1 września 1900 r. Komisja pełniła zarazem funkcję legislatywy, natomiast wojsku powierzono rolę władzy wykonawczej do czasu utworzenia rządu cywilnego, co nastąpiło 4 lipca $1901 \mathrm{r}$. Tego samego dnia gubernatorem wojskowym Filipin został gen. Adna Chaffee, który bez entuzjazmu dzielił się władzą ze swym cywilnym odpowiednikiem. Częste spory pomiędzy nimi oparły się ostatecznie o prezydenta (którym był już wówczas Theodore Roosevelt) i zostały przezeń załagodzone, choć nie zmieniło to negatywnego nastawienia wojskowych do władz cywilnych.

Kwestią, z którą Waszyngton musiał się jak najszybciej zmierzyć, było wpisanie planowanych wobec Filipin przedsięwzięć w mechanizm ekspansji terytorialnej państwa. Gdyby celem ostatecznym było uczynienie z Filipin stanu, za podstawę takich działań należałoby uznać Ordonans Północno-Zachodni z 1787 r., szczegółowo określający wymagania trójstopniowej procedury stawania się nowym stanem Unii: dystrykt-terytorium-stan ${ }^{13}$. Ale ratyfikując traktat paryski, Senat przyjął zarazem rezolucję McEnery’ego, zgodnie z którą odrzucono możliwość aneksji Filipin i uznania ich za stan ${ }^{14}$, uznając jedynie stałą suwerenność Stanów Zjednoczonych nad tym krajem. Jak ujął to senator William Allen:

„Jeśli weszliśmy w posiadanie archipelagu, jeśli jest on teraz pod każdym względem częścią terytorium Stanów Zjednoczonych, to Konstytucja Stanów Zjednoczonych rozciąga się na każdą z tych wysp i chroni każdego z mieszkańców. Jeśli nie weszliśmy w posiadanie tego obszaru, jeśli należy on do nas czasowo jako zdobycz wojenna...

\footnotetext{
13 http://avalon.law.yale.edu/18th_century/nworder.asp (dostęp 10 kwietnia 2014 r.).

14 Było to spowodowane w znacznej części uprzedzeniami rasowymi, co najwyraźniej dało się zauważyć w wystąpieniu senatora G.G. Vesta, który wykpiwał pomysł przyznania obywatelstwa amerykańskiego „na wpół cywilizowanym, pirackim, szalonym mieszkańcom dwóch tysięcy wysp"; http://archive.org/stream/ jstor-25119132/25119132_djvu.txt (dostęp 25 kwietnia 2014 r.).
} 
wówczas postanowienia Konstytucji nie mają zastosowania do terytorium i mieszkańców"15.

Problem polegał na tym, że nie istniały żadne uregulowania prawne odnoszące się do nowych ziem, które nie miały zostać włączone do Stanów Zjednoczonych. Wobec braku takich norm nie istniała prawna alternatywa dla traktowania Filipin jako obszaru wchodzącego w skład Stanów Zjednoczonych. To z kolei pociągało za sobą konsekwencje wynikające z powszechnie akceptowanej reguły, że „Konstytucja podąża za flagą", czyli że jej postanowienia obowiązują wszędzie tam, gdzie rządy sprawują Stany Zjednoczone - i to pomimo faktu, że nikt nie postulował uznania w przyszłości Filipin za stan Unii.

Debaty w Kongresie nie przyniosły konstruktywnych propozycji rozwiązania tego dylematu i kwestia została rozstrzygnięta dopiero przez Sąd Najwyższy w tzw. sprawach wyspowych (Insular Cases). Dotyczyły one posiadłości, które przypadły Stanom Zjednoczonym w konsekwencji traktatu paryskiego ze szczególnym uwzględnieniem Porto Rico, ale miały znaczenie i dla Filipin ze względu na regułę stare decisis. I tak na przykład w sprawie Fourteen Diamond Rings v. United States ${ }^{16}$ Sąd stwierdził, że „nie można przeprowadzić rozróżnienia między Filipinami a Porto Rico w kwestii stanowiącej przedmiot niniejszej sprawy" i zastosował bezpośrednio rozstrzygnięcie zapadłe w sprawie De Lima v. Bidwell ${ }^{17}$, dotyczącej Porto Rico.

W zależności od interpretacji, za pakiet Insular Cases uznaje się od sześciu spraw z 1901 r. do szesnastu z lat 1901 - 1914. Istotą zapadłych w nich orzeczeń było stworzenie pojęcia tzw. terytorium nieinkorporowanego (unincorporated territory). Stanowi ono część składową obszaru Stanów Zjednoczonych, ale w odróżnieniu od terytoriów inkorporowanych (jakimi były wówczas Hawaje czy Alaska) celem ostatecznym nie jest włączenie go do USA jako nowego stanu, a jego mieszkańcy nie są obywatelami amerykańskimi. $Z$ tego powodu na jego obszarze mają

15 Za A. Kent, Boumediene, Munaf and the Supreme Court's Misreading of the Insular Cases s. 126; http://ir.lawnet.fordham.edu/cgi/viewcontent.cgi?article=1249\& context=faculty_scholarship (dostęp 13 maja 2014 r.).

16183 U.S. 176 (1901).

17182 U.S. 1 (1901). 
zastosowanie tylko niektóre postanowienia Konstytucji Stanów Zjednoczonych, a ich listę tworzy Sąd, rozpatrując kolejne sprawy ${ }^{18}$. Gdyby bowiem nie wprowadzić nowego pojęcia to, zdaniem Sądu Najwyższego, „nie można by wejść w posiadanie terytorium, wobec którego nie rozpatruje się możliwości uczynienia go stanem, ani wejść w posiadanie terytorium nieuznawanego za integralną część Stanów Zjednoczonych".

Takie ograniczenie nie jest właściwe pomimo faktu, że

„Konstytucja przyjmuje założenie, że co do zasady nie należy wchodzić w posiadanie terytorium, jeśli nie ma uzasadnionego domniemania, że może ono stać się godne zyskania statusu stanu"19.

Sąd ewidentnie starał się pogodzić normy konstytucyjne z rzeczywistością polityczną, czego mógł dokonać jedynie tworząc nową kategorię administracyjną „terytorium nieinkorporowanego”. Tym samym jednak stworzył nową doktrynę, zgodnie z którą „Konstytucja nie zawsze podąża za flagą".

Amerykański plan wobec Filipin zakładał poszanowanie lokalnych obyczajów przy jednoczesnym wprowadzaniu zasad wywiedzionych z tradycji amerykańskiej. Składał się on z trzech elementów: przygotowywania Filipińczyków do zarządzania własnym krajem, upowszechniania szkolnictwa i implementacji reform gospodarczych. Choć takie pojmowanie panowania kolonialnego pozytywnie odbiegało od postępowania państw europejskich, to na realizacji planu negatywnie zaważył wyraźny rasizm administratorów amerykańskich. Powodzenie przemian społecznych zależało bowiem w znacznej mierze od dobrej współpracy z niektórymi przynajmniej Filipińczykami, ci zaś z niechęcią reagowali na okazywane im przez Amerykanów lekceważenie - wzorowane skądinąd na stosunku do amerykańskich wolnych Murzynów. Filipińczyków określano zresztą powszechnie mianem „brązowych”, konotacja którego to słowa była niemal tożsama z określeniem „czarny”.

Przystępując do realizacji procesu usamodzielniania Filipin, William Taft w kilka miesięcy po przybyciu do Manili stwierdził, że „każdego

18 Nie było wśród nich na przykład prawa do bycia osądzonym przez ławę przysięgłych; por. s. 16.

19 Downes v. Bidwell, 182 U.S. 244 (1901), s. 311-312. 
obserwatora, czy to bliskiego, czy przypadkowego, uderza niezdolność tych ludzi do rządzenia się samemu"20. Pogląd ten podzielali i inni członkowie Komisji, choć sam Taft uważał zarazem, że „polityką państwa [amerykańskiego] powinno być zarządzanie Filipinami dla dobra, dobrobytu i poprawy bytu ich ludności" ${ }^{21}$. Wypowiedzi takie mają niewątpliwie posmak protekcjonalizmu, ale jednocześnie wskazują na chęć realizacji koncepcji „dobrotliwego mocarstwa”, benevolent empire, nakreślonej przez prezydenta McKinleya: „Filipiny należą do nas nie po to, by je wyzyskiwać, lecz by je rozwijać, cywilizować i edukować"22. A sekretarz wojny Root dodawał, że obowiązkiem Stanów Zjednoczonych jest dać mieszkańcom Filipin

„jak najwięcej wolności indywidualnej, samostanowienia współmiernego do ich możliwości, sprawiedliwych i równych praw, sposobności edukacyjnych, dochodowej przedsiębiorczości i rozwoju cywilizacyjnego"23.

Kwestią niedopowiedzianą pozostawał natomiast horyzont czasowy tego przedsięwzięcia, który z pewnością wykraczał poza okres kadencji prezydenckiej. Problem Filipin stał się w ten sposób jednym z tematów walki partyjnej w Stanach Zjednoczonych, co miało wyraźnie dać o sobie znać z chwilą, gdy egzekutywa przekazała Kongresowi prowadzenie polityki w tym zakresie.

Dla powodzenia planu doprowadzenia do samorządności Filipin duże znaczenie miało dokooptowanie 1 września 1901 r. do Komisji Filipińskiej trzech lokalnych przedstawicieli, z których dwaj, Benito Legarda i Trinidad H. Pardo de Tapera, odegrali szczególnie istotną rolę. Obaj rozpoczęli karierę polityczną u boku Emilio Aguinaldo, ale rozstali się z nim już w końcu 1898 r. z powodu swego przekonania, że

20 Za T. Smith, America's Mission, Princeton University Press, Princeton 1994, s. 43.

21 Za M.K. Matsuda, Pacific Worlds, Cambridge University Press, Cambridge 2012, s.257.

22 Za Ch.H.A. Forbes-Lindsay, The Philippines Under Spanish and American Rules, Kindle edition, s. 203.

${ }^{23}$ Za J.R. Holmes, Theodore Roosevelt and World Order, Potomac Books, Washington 2006, s. 135. 
oddanie wysp pod kontrolę USA będzie korzystne dla kraju. W $1900 \mathrm{r}$. należeli do założycieli Partii Federalnej, która rok później miała już ponad 200 tys. członków, a jej program zakładał współpracę z Amerykanami. Taką postawę określa się w brytyjskiej tradycji kolonialnej mianem collaboration, co jednak nie zawiera, jak w polskim terminie „kolaboracja”, pejoratywnej oceny takiego postępowania i jest bliższe określeniu „współpraca”. Nie zmienia to faktu, że postawę Legardy i de Tavery, a także kilku innych Filipińczyków niektórzy historycy filipińscy postrzegają w kategoriach zdrady ${ }^{24}$.

Po kilku latach obaj wycofali się z życia politycznego, a ich miejsce u boku Amerykanów zajęli Sergio Osmeña i Manuel Quezon, członkowie powstałej w 1907 r. Partido Nacionalista. Po 1910 r. stali się oni krytykami Ameryki i Komisji Filipińskiej, ale jedynie w wystąpieniach publicznych; prywatnie nadal wyrażali wątpliwości w kwestii przygotowania Filipin do sprostania wymogom pełnej suwerenności, a także zdolności państwa do przeciwstawienia się ewentualnej agresji zewnętrznej, szczególnie ze strony Japonii ${ }^{25}$.

Kształtowanie się władzy filipińskiej wymagało też tworzenia samorządów miejskich. Początkowo Amerykanie próbowali wykorzystać $\mathrm{w}$ tym celu doświadczenia samorządowe $\mathrm{z}$ okresu kolonialnego w Nowej Angliii ${ }^{26}$, szybko jednak okazało się, że model ten nie przystaje do struktury społeczności filipińskiej, opartej na wyraźnej stratyfikacji wewnętrznej. Od samego natomiast początku pewne działania w kierunku reorganizacji miast filipińskich podjęło wojsko.

W sierpniu 1899 r. gen. Otis wydał General Order No. 43 ustanawiający system zarządów miejskich, które miały zajmować się zbieraniem podatków, utrzymywaniem czystości i innymi kwestiami zlecanymi przez dowódcę lokalnego garnizonu. O nader istotnym znaczeniu tego rozkazu stanowiło jednak nie określenie w nim kompetencji filipińskich władz miejskich, lecz wprowadzenie w przy ich elekcji powszechnego

24 Por. G.A. May, Social Engineering in the Philippines, Greenwood Press, Westport 1980, s. 28-30.

25 Por. ibidem, s. 37.

26 Por. Z. LEwicki, Historia cywilizacji amerykańskiej: Era tworzenia, Scholar, Warszawa 2009, s. 110-111. 
prawa wyborczego. Ta rewolucyjna zmiana nie zdążyła jednak wejść w życie, gdyż została zniesiona już w marcu następnego roku rozkazem General Order No.40/1900, który ograniczył prawo wyborcze do mężczyzn powyżej 23. roku życia, płacących stosunkowo wysokie podatki lub władających językiem angielskim albo hiszpańskim. Tak sformułowane kryteria ograniczyły elektorat do ok. 2\% ludności. Niemniej w efekcie przeprowadzonych we wrześniu 1900 r. wyborów Filipińczycy uzyskali pierwsze elementy autonomii, nawet jeśli nowe władze lokalne podlegały administratorom amerykańskim. Ustanowiono ponad tysiąc organów władzy lokalnej i 31 rządów poszczególnych prowincjii ${ }^{27}$. Był to początek programu nazwanego „dyscyplina i demokracja”, a ordynacja wyborcza i reguły wykonywania władzy przez samorządy miejskie zostały sformalizowane w Municipal Code, wydanym w styczniu $1901 \mathrm{r}$.

Ważnym elementem powodzenia planu zbudowania na Filipinach demokracji opartej na doświadczeniach amerykańskich było przyjęcie w 1901 r. przez Kongres tzw. poprawki Spoonera. Budziła ona duże kontrowersje w Izbie Reprezentantów i została początkowo odrzucona, ale później dołączono ją do ustawy zapewniającej finansowanie armii, którą Kongres z oczywistych względów musiał zaakceptować. Uregulowanie to wyposażało władzę wykonawczą w szerokie uprawnienia w odniesieniu do Filipin.

Postanowienia poprawki zostały następnie zastąpione uchwaloną w lipcu 1902 r. Ustawą organiczną (Organic Act), zwaną także Ustawą Coopera lub Ustawą filipińską ${ }^{28}$, regulującą całość kwestii związanych z zarządzaniem Filipinami. Terminem „akt organiczny” określa się $\mathrm{w}$ amerykańskiej tradycji legislacyjnej przepisy ustanawiające organy władztwa na obszarach (terytoriach) należących do Stanów Zjednoczonych i zmierzających do uzyskania statusu stanu. Ten quasi-konstytucyjny dokument uregulował podstawowe zasady funkcjonowania Filipin jako posiadłości amerykańskiej, ustalał uprawnienia i obowiązki mieszkańców archipelagu oraz określał strukturę władzy na Filipinach.

27 Por. F.H. Golay, Face of Empire, University of Wisconsin Press, Madison 1998, s. 70.

2832 Stat. 691, ch. 1369; http://www.gov.ph/constitutions/the-philippine-organic-act-of-1902/ (dostęp 20 kwietnia 2014 r.). 
Filipińczyków uznano w nim za wards of the U.S. government, czyli osoby podlegające władzy prawnego opiekuna, jakim był rząd Stanów Zjednoczonych, i stwierdzano, że na terenie Filipin nie można stosować wprost Konstytucji amerykańskiej.

Rozwiązanie to pociągało jednak za sobą nieprzewidziane przez ustawodawcę konsekwencje. W sprawie Dorr v. United States ${ }^{29}$, dotyczącej konieczności przeprowadzenia procesu przed ławą przysięgłych, co gwarantuje Konstytucja Stanów Zjednoczonych, Sąd orzekł, że „na mocy samej tylko Konstytucji, bez odrębnej legislacji, nie można przenosić tego prawa na terytorium [scedowane]"30. Ale sędzia John Marshall Harlan zwrócił uwagę w zdaniu odrębnym, że jest to rozwiązanie potencjalnie krzywdzące dla każdego z tysięcy przebywających na wyspach żołnierzy amerykańskich, którzy, „jeśli zostaną oskarżeni na Filipinach o przestępstwo przeciw Stanom Zjednoczonym, a sąd cywilny uzna swoją jurysdykcję, nie będą mogli zrealizować prawa do procesu przed ławą przysięgłych"31.

Ustawa organiczna pozostawiła wprawdzie Filipiny w kompetencjach Departamentu Wojny i jego Biura Spraw Wyspowych, ale jednocześnie ustanowiła na wyspie stałe struktury cywilne. Gubernator cywilny (zwany od 1905 r. Gubernatorem Generalnym) stał się jednoosobową władzą wykonawczą Filipin. Równolegle jednak z tworzeniem systemu rządztwa kolonialnego Stany Zjednoczone podjęły wysiłek budowania filipińskiej struktury państwowej, przygotowywanej do przejęcia w swoim czasie zarządu nad życiem politycznym i gospodarczym, a także sądownictwem niepodległego państwa filipińskiego.

Istotnym krokiem na drodze do stworzenia niepodległego państwa filipińskiego były przeprowadzone w 1907 r. wybory do izby niższej dwuizbowego parlamentu archipelagu; jego izbę wyższą stanowiła Komisja Filipińska. Warto zauważyć, że struktura taka, składająca się z mianowanego gubernatora, wyznaczanej izby wyższej, legislatury oraz pochodzącej z wyborów izby niższej (przy braku odrębnej władzy sądowniczej)

\footnotetext{
29195 U.S. 138 (1904).

30 http://supreme.justia.com/cases/federal/us/195/138/case.html, s. 154 (dostęp 30 kwietnia 2014 r.).

31 Ibidem, s. 155.
} 
była odwzorowaniem systemu obowiązującego we wszystkich trzynastu koloniach brytyjskich w Ameryce do czasu uzyskania przez nie niepodległości ${ }^{32}$. Sama Ustawa organiczna pozostawała w mocy do 1916 r., gdy Kongres przyjął Ustawę o autonomii Filipin, zwaną też Ustawą Jonesa.

W miarę upływu czasu nadzór amerykański ulegał rozluźnieniu, a autonomia filipińska rosła, obejmując nawet pobór podatków czy zapewnianie porządku publicznego. Po zakończeniu walk z siłami Aguinaldo zadanie utrzymywania porządku przejęła nowo utworzona policja filipińska, Philippine Constabulary: „w 1904 r. Constabulary składała się z ok. 345 Amerykanów i mniej więcej 7 tys. Filipińczyków rozlokowanych na 250 posterunkach w całym kraju"33. Kierowano się zasadą, że „miało być tyle autonomii, by lokalni urzędnicy mogli zdobywać doświadczenie, wypełniając funkcje rządowe, i tyle kontroli, by mogli sprawować je prawidłowo oraz skutecznie uczyć się na błędach" ${ }^{34}$. Przybyli amerykańscy urzędnicy służby cywilnej szybko jednak odkryli, że ich filipińscy podwładni defraudują środki publiczne, a podlegające im siły porządkowe traktują jak własnych służących. Ale dość powszechna korupcja wśród urzędników filipińskich nie zniechęcała Amerykanów, a przychwyceni na niej oficjaliści w większości albo nie tracili stanowisk, albo obejmowali inne na zbliżonym poziomie.

Poważnym problemem pozostawał bowiem długi z natury proces wyłaniania się naturalnych przywódców lokalnych, szczególnie po stratach związanych ze stłumioną rewoltą. Spowodowało to umocnienie się powstałej za czasów hiszpańskich warstwy kacyków, cacique, czyli lokalnych przywódców mianowanych przez ówczesne władze kolonialne. Administratorzy a merykańscy, potępiając werbalnie system „demokracji kacyków”, w praktyce korzystali z niego dla zapewnienia efektywności swoich rządów oraz ,jedności i jednolitości administracji prowincji i miast na wyspach"35. W grę wchodziła też specyfika lokalna. Gdy, na

\footnotetext{
32 Por. Z. LEWICKI, op.cit., s. 20-21.

33 R.T. Jose, The Philippine Army, 1935-1942, Ateneo da Manila University Press, Quezon City 1992, s. 18.

34 J. Go, The Chains of Empire, [w:] The American Colonial State in the Philippines, red. J. Go, A.L. Foster, Duke University Press, Durham 2003, s. 190.

35 J.R. Hayden, The Philippines, Arno Press, New York 1972, s. 272.
} 
przykład, urzędnicy nakładali nielegalne podatki, tylko część tak pozyskanych przychodów trafiała do ich kieszeni, część zaś przeznaczano na przykład na budowę dróg, na co w budżecie często brakowało pieniędzy.

Na tolerancję wobec nadużyć władz miejskich miała też wpływ zbieżność czasowa kolonizacji Filipin z niekorzystnymi zjawiskami społecznymi zachodzącymi podówczas w samych Stanach Zjednoczonych. Był to bowiem okres potężnych miejskich machin partyjnych (takich jak Tammany Hall w Nowym Jorku) i wynikającej z tego zjawiska dość powszechnej korupcji politycznej w Ameryce.

Machiny partyjne zawdzięczały swoją potęgę zjawisku patronatu, czyli obsadzania ważnych stanowisk we władzach miejskich i stanowych wytypowanymi przez siebie ludźmi, którzy rewanżowali się przyznawaniem kontraktów budowlanych czy transportowych przedsiębiorcom współpracującym z daną partią. To z kolei nie tylko umożliwiało machinom bogacenie się na zawyżanych, często bardzo znacznie, kosztach realizacji, lecz także dawało im możliwość zatrudniania lokalnych bezrobotnych czy nowych imigrantów, którzy w zamian łamali prawo i wielokrotnie głosowali na kandydatów wskazanej partii ${ }^{36}$. Zmiany przyniósł dopiero na początku XX w. ruch reformatorski określany mianem progresywizmu, w którym dużą rolę odegrał prezydent Theodore Roosevelt. Choć historia kształtowania się systemu władztwa na Filipinach miała odmienny przebieg, to i tam na początku XX w. widoczne było współistnienie dwóch niekompatybilnych podsystemów: izolowanych przykładów uczciwej administracji lokalnej i znacznie powszechniejszych przejawów korupcji opartej na mechanizmie patronatu.

Tworzenie struktur państwowych utrudniał też fakt, że Filipiny były niejednorodne pod względem kulturowym. Część prowincji można było określić mianem „ucywilizowanych”. Ich mieszkańcy byli chrześcijanami, a silne miejscowe elity zapewniały ciągłość władzy przy przejściu spod panowania Hiszpanii pod amerykańskie rządy kolonialne. $\mathrm{Z}$ drugiej strony szereg prowincji, z reguły odległych od wyspy Luzon,

\footnotetext{
36 W Stanach Zjednoczonych bardzo długo obowiązywało głosowanie viva voce $\mathrm{i}$ - przy braku list wyborczych - poleganie na własnej deklaracji wyborcy o posiadaniu prawa do głosowania.
} 
charakteryzowano jako „niepodporządkowane”, gdyż miejscowa ludność nie przyjęła wiary chrześcijańskiej i nie uznawała władzy hiszpańskiej, a później amerykańskiej. W rezultacie Filipiny nie stanowiły zwartej całości i Amerykanie rozpatrywali możliwość zarówno siłowej ich integracji, jak i wydzielenia „niepodporządkowanych” prowincji ${ }^{37}$.

Ostatecznie przeważyła opcja zachowania jedności kolonii, a rozpoczęty po stłumieniu rewolty proces budowy struktur przyszłego niepodległego państwa filipińskiego przynosił efekty. Kluczowe znaczenie dla powodzenia tego procesu miała gotowość do współpracy elit filipińskich, co pozwalało im z jednej strony przejmować i umacniać kontrolę w lokalnych, a następnie krajowych organach władzy, a z drugiej, współkształtować struktury przyszłego niepodległego państwa.

Czerpiąc z doświadczeń procesu wdrażania nowoczesnej służby cywilnej, zapoczątkowanego w Stanach Zjednoczonych w 1883 r. wprowadzeniem Ustawy Pendletona, ustanowiono też egzaminy na stanowiska w administracji centralnej Filipin, tworząc w ten sposób ,jeden z najbardziej udanych tworów współpracy amerykańsko-filipińskiej... służbę cywilną opartą na bezkompromisowym stosowaniu zasady zasług” i „nowoczesny rząd o wyjątkowym poziomie uczciwości i efektywności”38.

Nawet w dwóch „niepodporządkowanych” prowincjach, czyli w pogańskiej Prowincji Górskiej na wyspie Luzon oraz w islamskiej Prowincji Moro na wyspie Mindanao, zarządzanych przez administratorów wojskowych na podstawie prawa o stanie wojennym, a nie przez amerykańskich czy filipińskich urzędników cywilnych, udało się zrealizować szereg przedsięwzięć modernizacyjnych. Zarząd wojskowy miał jednak poważne niedoskonałości, z których najistotniejszą był obowiązujący w armii system rotacji, na czym cierpiała ciągłość sprawowania władzy w prowincjach.

Drugim obszarem działań amerykańskich na Filipinach było u s t a nowienie systemu powszechnego szkolnictwa na poziomie podstawowym, a nawet ponadpodstawowym. Jako pierwsze do

37 Szerzej na ten temat pisze P.W. Stanley, A Nation in the Making, Harvard University Press, Cambridge 1974.

38 J.R. HAYDEN, op. cit., s. 143, 93. 
jego tworzenia przystąpiło wojsko. W końcu 1900 r. objęto nim ponad 100 tys. dzieci filipińskich, które jednak z reguły zmuszone były uczęszczać do zatłoczonych szkół znajdujących się w budynkach niespełniających podstawowych wymogów dla tego typu instytucji. W styczniu $1901 \mathrm{r}$. Komisja Filipińska przyjęła Ustawę nr 74, tworzącą Biuro Nauczania Publicznego. Tym samym aktem ustanowiono scentralizowany system szkolnictwa podstawowego oraz zawodowego i rolniczego, a także studiów nauczycielskich. Nie wprowadzono natomiast obowiązku szkolnego, gdyż nie pozwalały na to warunki lokalowe. Co ciekawe, programy nauczania i strukturę szkół zawodowych wzorowano na znanych placówkach edukacyjnych dla amerykańskich Murzynów: Tuskegee Institute oraz Hampton Normal and Agricultural Institute.

Do pomocy w tworzeniu szkolnictwa filipińskiego przewidziano zatrudnienie ok. tysiąca nauczycieli amerykańskich. Wobec zaoferowania znacznie wyższych stawek niż w kraju, do pracy na wyspach zgłosiło się ponad 8 tys. kandydatów, zapał wybrańców znacznie jednak osłabł, gdy, wbrew zapowiedziom, okazało się, że uposażenie wypłacano im nie w dolarach amerykańskich, lecz w szybko tracącej na wartości miejscowej walucie.

Pierwszy dyrektor Biura Nauczania Publicznego okazał się bardzo mało operatywny i program zaczął funkcjonować dopiero pod kierownictwem Davida Barrowsa, który piastował tę funkcję w latach 1903-1909. Wierzył on w kulturotwórcze oraz gospodarcze znaczenie edukacji i koncentrował się na jak najszerszym wdrożeniu w życie nauczania opartego na tradycyjnej amerykańskiej koncepcji „trzech R”: reading, writing, 'rithmetic, czyli czytania, pisania i rachowania. Doprowadził też do opracowania i wydania wypisów szkolnych przystosowanych do rzeczywistości filipińskiej, ale skoncentrowanie się na demokratyzującej roli powszechnego nauczania sprawiło, że zaniedbał kształcenia umiejętności praktycznych, przydatnych w późniejszym życiu uczniów.

Następca Barrowsa porzucił ideę powszechności nauczania. O ile w pierwszej dekadzie XX w. liczba uczniów wzrosła do ponad 600 tys., to już w 1911 zmalała do nieco powyżej 500 tys., a w 1912 r. do niecałych 450 tys., co oznaczało, że „pół miliona dzieci w wieku szkolnym, czyli 
połowę dzieci filipińskich, pozbawiono edukacji”39. Z drugiej jednak strony nawet ten ograniczony sukces był znacznie większy niż w porównywalnych z Filipinami Indiach Holenderskich czy Birmie ${ }^{40}$.

Kwestią kluczową dla uznania przez Filipińczyków obecności Amerykanów na wyspach za korzystną dla nich i dla kraju było jednak zrealizowanie trzeciego celu, czyli osiągnięcie sukcesu gos p o d a r c z e g o. Podstawową cechą kolonializmu europejskiego była eksploatacja gospodarcza, natomiast kolonializm amerykański na Filipinach był jej całkowicie pozbawiony, gdyż Stany Zjednoczone nie odczuwały braku surowców czy minerałów występujących na Filipinach. Ukształtowanie polityki gospodarczej leżało w kompetencjach legislatury, a nie egzekutywy, ale członkom Kongresu brakowało wiedzy niezbędnej do opracowania planu ekonomicznego dla Filipin.

Wiedzą taką dysponowała Komisja Filipińska, ale jej uprawnienia w zakresie gospodarki sprowadzały się niemal wyłącznie do budowy dróg. Niemniej Komisja wskazała trzy obszary niezbędne dla osiągnięcia przez mieszkańców archipelagu wyższej stopy życiowej: po pierwsze, inwestycje w rolnictwo i przemysł wydobywczy; po drugie, obniżenie importowych stawek celnych przez Stany Zjednoczone; po trzecie, budowa dróg i kolei na wyspach oraz połączeń transportowych pomiędzy nimi.

Rolnictwo filipińskie dysponowało szerokimi możliwościami zwiększenia upraw łatwo sprzedawalnych (cash crops), a stworzenie wielkich plantacji cukru czy tytoniu byłoby korzystne dla gospodarki kraju. W trakcie prac nad Ustawą organiczną z 1902 r. gubernator Taft silnie lobbował za umożliwieniem inwestorom zakupu terenów rolniczych o powierzchni do 2 tys. ha, ale ostatecznie Kongres zezwolił rządowi Filipin jedynie na sprzedaż lub oddawanie w dzierżawę obszarów o połowę mniejszych. Miało to niekorzystny wpływ na gospodarkę archipelagu i skłoniło Tafta do sformułowania istotnej konstatacji: „Zasada, że żadna korporacja nie może posiadać więcej niż tysiąc ha ziemi, całkowicie

\footnotetext{
39 A.J. Angulo, Empire and Education, Palgrave Macmillan, New York 2012, s. 28.

40 Por. J.S. Furnivall, Netherlands India, Cambridge University Press, Cambridge 2010, s. 364-377; Idem, Educational Progress in Southeast Asia, Institute of Pacific Relations, New York 1943, s. 56.
} 
wstrzymuje napływ nowego kapitału do przemysłu cukrowniczego i tytoniowego" ${ }^{1}$.

Na wyspach znajdowały się też złoża złota, węgla, miedzi i żelaza, ale dotarcie do nich wymagało zaangażowania poważnych środków na zakup maszyn. Ustawa organiczna wprowadziła jednak ograniczenie wielkości działki nabywanej dla celów wydobywczych do 10 tys. $\mathrm{m}^{2}$, wskutek czego wydobywanie surowców stawało się nieopłacalne. Inna sprawa, że ograniczenie to chroniło zarazem prawa ludności rdzennej i pozwoliło aż do lat 30 . XX w. uniknąć sporów z Amerykanami na tym tle, co z perspektywy czasu można uznać za zjawisko korzystne dla Filipin.

W kwestii ceł od $1897 \mathrm{r}$. w amerykańskim handlu zagranicznym obowiązywała tzw. tabela celna Dingleya, Dingley Tariff, która ustanowiła najwyższe $\mathrm{w}$ historii państwa cła importowe, sięgające średnio 50\% wartości towaru. Zgodnie jednak z orzeczeniami Sądu Najwyższego w sprawach wyspowych, Filipiny nie były „państwem obcym” i tabela Dingleya nie miała w stosunku do nich zastosowania. Zarazem Filipiny nie były też częścią Stanów Zjednoczonych, co dało Kongresowi prawo do zadecydowania o obowiązującym wobec nich systemie celnym, od czego z kolei zależała atrakcyjność wysp dla amerykańskich inwestorów. Komisja Filipińska postulowała ograniczenie ceł importowych do poziomu 25\% tabeli Dingleya.

Pod silnym naciskiem amerykańskich plantatorów tytoniu i buraka cukrowego przyjęta w marcu 1902 r. Ustawa o cle filipińskim ustanowiła je jednak na poziomie $75 \%$ tabeli, co przy znacznej odległości wysp od kontynentu amerykańskiego (i jednoczesnym wprowadzeniu wolnego handlu $\mathrm{z}$ Porto Rico) nie pozwalało na stworzenie dochodowego modelu handlu i zapewnienie rozwoju gospodarczego Filipin. Ustawa została zmieniona dopiero w 1909 r., gdy ustanowiono wolne od cła kwoty przywozowe dla filipińskiego cukru i tytoniu na poziomie znacznie przekraczającym możliwości eksportowe tego kraju. Natomiast w $1913 \mathrm{r}$. przyjęto tabelę celną Underwooda (Underwood Tariff), która ustanowiła całkowicie wolny handel między USA a Filipinami.

41 Za G.A. MAY, op. cit. s. 153. 
Choć ograniczenia gospodarcze narzucone przez Ustawę organiczną utrudniały zaangażowanie się kapitału amerykańskiego, to dla elit filipińskich czas kolonizacji amerykańskiej był okresem wielkich możliwości. O ile Hiszpania ściśle ograniczała swego czasu eksport filipiński, o tyle przybyli na wyspy Amerykanie ułatwiali lokalnym inwestorom pozyskiwanie kredytów i dostęp do globalnego rynku produktów rolnych. Pozwoliło to lepiej wykształconym i ulokowanym przedsiębiorcom filipińskim skutecznie powiększać swe majątki dzięki eksportowi do Europy i Ameryki nie tylko tytoniu i cukru, lecz także bananów manilskich czy kopry. Poza zyskami bezpośrednimi ułatwiło to również wykształcenie się na Filipinach znacznie szerszej niż uprzednio klasy przedsiębiorców, którzy z czasem stworzyli lokalną odmianę kapitalizmu przemysłowego.

Specyficznym elementem gospodarki filipińskiej na początku XX w. było natomiast formalne przyzwolenie władz amerykańskich na opodatkowaną sprzedaż opium. Pomimo protestów działaczy progresywistycznych pozostawało ono w tym czasie legalne w samych Stanach Zjednoczonych. Nie brakowało lekarzy uważających opium za cudowne lekarstwo na wiele dolegliwości, choć zarazem kojarzono je negatywnie $\mathrm{z}$ imigracją chińską, co spowodowało ograniczenie jego dostępności w USA do zarejestrowanych palarni, zwanych opium dens. Ustawa Smoking Opium Exclusion Law z 1909 r. formalnie ograniczyła legalną konsumpcję opium i pochodnych właśnie do ich palenia (w przeciwieństwie do formy sproszkowanej lub płynnej), a Ustawa Harrisona z 1914 r. uregulowała kwestie importu i opodatkowania opiatów.

W okresie hiszpańskiej kolonizacji Filipin tylko lokalne władze miały prawo importować nasiona maku lekarskiego (opium poppy) i odsprzedawać je wyznaczonym właścicielom pól uprawnych, którzy z kolei mogli sprzedawać narkotyk tylko Chińczykom. Po przejęciu wysp przez Amerykanów system ten pozostał w mocy przede wszystkim ze względu na realistyczną konstatację, że zakazy spowodują jedynie wzrost przemytu. Zwolennikiem pozostawienia status quo był także gubernator Taft, który argumentował, że istniejący system pozwala władzom kolonialnym nie tylko uzyskiwać potrzebne fundusze, lecz także kontrolować handel opiatami. Dopiero w marcu 1905 r. Kongres 
uchwalił zakaz sprowadzania nasion maku na Filipiny, wyznaczając wejście w życie nowego przepisu na marzec $1908 \mathrm{r}$.

Kolejną dziedziną, której rozwój Komisja Filipińska uznała za niezbędny dla dobrobytu kraju, było usprawnienie systemu transportowego, na co składała się budowa dróg, linii kolejowych i urządzeń portowych. Była to jedyna kwestia, w której Komisja mogła podejmować samodzielne decyzje, ograniczane jedynie dostępnością środków finansowych. Wobec limitów w tym zakresie Komisja zaproponowała w 1904 r. wprowadzenie dla wszystkich zdrowych Filipińczyków obowiązku pracy przy budowie dróg w wymiarze pięciu dni w roku, co można było zastąpić wpłatą stosownej kwoty na ten sam cel. Uregulowanie to musiało jednak zostać zatwierdzone przez zarządy poszczególnych prowincji i choć sieć drogowa pozwoliłaby zwielokrotnić eksport $\mathrm{z}$ oczywistą korzyścią dla mieszkańców, żadna z części archipelagu nie zdecydowała się wprowadzić w życie tego postanowienia.

W tej sytuacji w 1907 r. Komisja wystąpiła z propozycją podwojenia wysokości pogłównego z przeznaczeniem dodatkowego przychodu na rozwój sieci transportowej. Prowincje, które wyraziłyby na to zgodę, miały otrzymać od Amerykanów wysokie kwoty na budowę dróg. Tym razem wszystkie $\mathrm{z}$ nich przyjęły w ciągu dwóch lat to rozwiązanie. Do 1913 r. udało się także zbudować $800 \mathrm{~km}$ nowych linii kolejowych (a zezwoleń udzielono na ponad 1,2 tys. km) i zmodyfikować niektóre porty.

Choć w II połowie XX w. w historiografii amerykańskiej daje się zauważyć silny nurt obwiniający polityków amerykańskich z początku wieku o praktykowanie bezwzględnego imperializmu gospodarczego ${ }^{42}$, trudno nie dostrzec, że przynajmniej w przypadku Filipin obecność Amerykanów przyniosła krajowi i jego mieszkańcom wymierne korzyści. Dążąc do przeniesienia na wyspy możliwie wielu aspektów swojej cywilizacji, Amerykanie budowali drogi, tworzyli system łączności,

42 Tendencję tę zapoczątkował w 1959 r. W.A. Williams książką The Tragedy of American Diplomacy, stanowiącą czołową pozycję historiografii amerykańskiej tworzonej z pozycji Nowej Lewicy. 
a przede wszystkim zainicjowali program edukacyjny i program ochrony zdrowia. Stany Zjednoczone nie potrzebowały kolonii jako źródła własnego dobrobytu ekonomicznego i nie widziały potrzeby uciekania się do klasycznej eksploatacji kolonialnej na wzór hiszpański czy brytyjski. Budowany z wolna Pax Americana nie był, jak Pax Romana czy Pax Britannica, oparty na podboju obcych ziem i podporządkowaniu sobie miejscowej ludności, lecz na poczuciu „specjalnej misji globalnej, by przekształcić i zbawić inne narody, przede wszystkim poprzez dawanie przykładu z własnych instytucji republikańskich... Stany Zjednoczone proponowały całkowitą nowość w historii: nie imperium, lecz «,ekspansywny republikanizm»; nie kolonialne rządy, lecz «naukę samorządności»; nie ucisk, lecz «życzliwą asymilację»" ${ }^{43}$.

Kolonializm nie ogranicza się do wymiaru gospodarczego i politycznego, gdyż nie mniej istotne są kwestie dominacji intelektualnej. Amerykanie stosowali na Filipinach mechanizmy inżynierii społecznej ukierunkowane na dokonanie istotnych przemian w systemie wartości kolejnych pokoleń skolonizowanego narodu. Czynili to jednak z zachowaniem istniejącej tkanki społecznej i uważali, że wprowadzane reformy okażą się korzystne zarówno dla Stanów Zjednoczonych, jak i dla Filipin.

W zgodzie z ówczesnymi normami społecznymi, nie oznaczało to oczywiście akceptacji na równych prawach ludności miejscowej, czy nawet jej najbardziej wykształconej i majętnej warstwy. Ale realizatorom amerykańskiej polityki kolonialnej na Filipinach udało się sprawić, że miejscowe elity gospodarcze i polityczne współpracowały z nimi, a płynące stąd korzyści odczuli także Filipińczycy z niższych warstw. Umożliwiło to bezkonfliktowe przeprowadzenie procesu uzyskiwania przez Filipiny niepodległości. W 1934 r. powstała administracyjna struktura państwowa, określana mianem Philippine Commonwealth ${ }^{44}$, po kolejnej dekadzie i okresie okupacji japońskiej podczas II wojny światowej przekształcona w suwerenne państwo filipińskie. W październiku

\footnotetext{
43 P.A. Kramer, Empires, Exceptions, and Anglo-Saxons, [w:] The American Colonial State in the Philippines..., s. 49, 75.

44 To tradycyjne brytyjskie pojęcie nie ma jednoznacznego odpowiednika w języku polskim. Z jednej strony British Commonwealth oddaje się jako Brytyjska Wspólnota Narodów, z drugiej zaś w historiografii anglojęzycznej termin Commonwealth pojawia się np. w odniesieniu do Rzeczypospolitej Obojga Narodów.
} 
1945 r. Filipiny stały się członkiem-założycielem Organizacji Narodów Zjednoczonych, a 4 lipca 1946 r., czyli w dniu święta narodowego USA, kraj ten formalnie uznał Filipiny jako w pełni suwerenne państwo.

Establishing American Colonial Government in the Philippines

\section{Summary}

The Philippines was the only American colony and its establishment caused a fierce debate in the United States on whether this complied with the principles of American civil society. It was decided that returning the archipelago to Spain or simply abandoning it was out of the question, and that the USA would retain its sovereignty over the islands while preparing the country for independence.

This is in fact what happened. After the period of military struggle with the forces of Emilio Aguinaldo, Americans began what would today be described as a nation-building process. Its most important components were the health system and education, along with the training of administrative staff, who assumed more and more responsibility. This was in stark contrast with the behaviour of traditional colonial powers.

While the process was somewhat slower than expected, and was interrupted by the outbreak of World War 2, the Philippines became independent soon after the war and the process of transition was conducted in an orderly fashion.

The article, the first on the topic in Poland, analyses the successive phases in the building up of American colonial control of the Philippines and its subsequent withdrawal.

Słowa kluczowe: Filipiny, Stany Zjednoczone, kolonizacja, status polityczny, status prawny.

Keywords: the Philippines, the United States, colonization, political system, legal status. 